\title{
Concealed in the Open: Recipients of International Clandestine Jewish Aid in Early 1950s Hungary
}

Zachary Paul Levine, Yeshiva University Museum, New York

Abstract: This article discusses the emergence of the semi-clandestine efforts of a network of international Jewish philanthropies and the Israeli government to send material and financial aid to Jews in early-communist Hungary. Post Second World War Hungary was a special focus for Jewish aid organizations in the west and the Israeli government. They poured resources into Hungary, both to feed, cloth and provide medical care to hundreds of thousands of Jews, and to assist thousands of Jews migrating west through Hungary. The American Jewish Joint Distribution Committee, the dominant Jewish aid organization in the world at the time, ran its largest and most expensive program in Hungary. Working with Israeli and Hungarian authorities, it financed a network of welfare services, often through the importation of scarce consumer goods and raw materials. As the Communist Party reshaped the economy, and pushed out "undesirable elements" from Hungarian life, this aid program served a growing population of impoverished, sick, and religious Jews, some exiled in Hungary's countryside. This program increasingly took advantage of black market networks to distribute aid. Yet, after conditions deteriorated so much that this program ceased officially, Jewish aid providers in the US and Israel adapted their earlier practices and networks to take advantage of the impoverished consumer economy in program to distribute aid clandestinely to Hungarian Jews, with the cooperation of Hungary's communist authorities.

Keywords: Jews, black market, humanitarian aid, Israel, Joint Distribution Committee

Biography: Zachary Paul Levine is a curator at Yeshiva University Museum where he develops exhibitions on the intersection of modern Jewish history and contemporary art. He conducted his historical research while a doctoral student at New York University in the departments of Hebrew and Judaic Studies and History. Mr. Levine presented many of the findings in this paper at the Center for Jewish History in March 2010. He received an MA in History from Central European University, and BAs in Government and Politics and Jewish Studies from the University of Maryland.

The first years of communist rule were unkind to much of the Hungarian population in general, with a substantial number of Jewish survivors especially affected. Beginning after the end of the Second World War, most of Hungary's Jews received direct life-saving assistance from the American Jewish Joint Distribution Committee's (AJDC or Joint), whose humanitarian program in Hungary was its largest in Europe. Aside from the requirements of postwar rebuilding, the wrenching process of nationalization that bequeathed economic and social stigma to many Jews, lingering anxieties from political purges, deportations and arrests, the constant threat of the Secret Police, and the devastating impact of the economic planning of Mátyás Rákosi's communist regime, made the postwar economic and political situation all the more 
Levine, Zachary Paul. "Concealed in the Open: Recipients of International Clandestine Jewish Aid in Early 1950s Hungary” AHEA: E-journal of the American Hungarian Educators Association, Volume 5 (2012):

http://ahea.net/e-journal/volume-5-2012

grim. The protracted decline and collapse of the AJDC's Hungary program in January 1953, the last AJDC program operating openly in a communist state, seemed to signal the end of Jewish aid to Eastern Europe. Yet, as the following discussion illustrates, this did not mean the abandonment of the tens-of-thousands of Hungarian Jews reliant on help from abroad.

After 1949, the AJDC's program became the object of growing east-west antipathies.

Yet, in spite of the Joint's discordant relationship with the Rákosi government, which resulted in the protracted shutdown of the AJDC's official program, its American and west-European leadership found ways to continue providing some assistance, albeit clandestinely, that is through third parties. In a partnership that stretched back to the Second World War, the AJDC, the Israeli government, and networks of Jewish and non-Jewish philanthropic organizations around the world found ways to provide indirect if not clandestine financial and material assistance to Hungary's neediest Jews. Working in tandem, AJDC and Israeli leaders sought to aid sick and elderly victims of fascism, Jews who had subsequently lost their livelihood and their homes because of nationalization, thousands of unemployed orthodox, and others unable to support themselves. Between 1951-1953 this program encompassed a series of ad-hoc schemes to get a few dollars and items for sale on the black market into the hands of the neediest people in the Hungarian-Jewish population. After 1953, this program developed into an aid regimen. The agreements between a Swiss AJDC-Israeli proxy and Hungarian authorities to formalize clandestine aid during the New Course reforms, conformed both to the wider geo-political environment and the economic situation in Hungary. Within less than five years, and with the consent and assistance from western and east European governments who accepted working with a non-American third party, this AJDC-Israeli partnership came to provide individual economic assistance to over half of Hungary's Jews, and bolstered Jewish welfare institutions. In this case, Jews accounted for self-identified Jews, or individuals who had been categorized as Jewish by the wartime regime.

This article discusses the emergence, distribution, use and significance of clandestine aid during the first decade of communist Hungary. It argues that, while the Cold War and Hungarian economic and political environment created a situation necessitating clandestine aid, it also shaped the ways that providers distributed aid, and how recipients used that aid. Indeed, the diffusion of much of this aid appears to have been sufficiently widespread and visible so as to bring into question the extent to which AJDC aid was in fact clandestine. I draw on correspondence between Jewish aid providers in America and Hungary, and Israeli and American officials, as well as published and archival materials from Hungarian Jews who received aid, orchestrated its distribution in Hungary and abroad, or worked in Jewish welfare institutions (Detailed references, while unavailable in this version, appear in previous presentations related to this study delivered at the Center for Jewish History in March 2010 and the Association for Jewish Studies Annual Conference in December 2010).

\section{Official Aid and its Economic Context, 1945-1953}

Yehuda Bauer's (1989: 135-46) statement that Jews in post-Second World War Hungary "had no food, no strength, and as a result they could not find employment" tells only part of the story. As the immediate humanitarian crisis settled, the economic situation, and the Communist Party's solutions to its challenges, perpetuated new problems. Postwar hyperinflation wiped out savings and wrecked businesses, Soviet demands for reparations strangled Hungary's industrial capacity, and the economic centralization that was supposed to improve the situation decimated 
Levine, Zachary Paul. "Concealed in the Open: Recipients of International Clandestine Jewish Aid in Early 1950s Hungary” AHEA: E-journal of the American Hungarian Educators Association, Volume 5 (2012):

http://ahea.net/e-journal/volume-5-2012

domestic production of consumer goods. The nationalization of private businesses under the first Three-Year plan had especially harsh ramifications for the large numbers of Jews in retail and light industry, and in particular in textiles. As many as 7,000 out of the estimated 25,000 Jewish merchants in Hungary needed retraining to work outside of commerce. Roughly 1,000 of the 18,000 Jewish textile tradesmen, who comprised the bulk of that 19,000-strong sector, retained their positions after the second round of nationalizations in 1948. These figures represented not only individuals, but also single-income households. The few people managing temporarily to maintain a private business faced punitive taxes, were dependent on state-owned sources for raw materials and financing, and were in competition with state-owned stores privy to specially priced supplies (Duschinsky 1953: 452-53). Individuals who found employment in state companies - though not necessarily in their prewar occupations-typically received substantially lower wages than before nationalization, usually insufficient to support a household. One estimate from 1948 found that, given these dire circumstances, roughly 95,000 Hungarian Jews were reliant on the American Jewish relief to make ends meet, mostly from the AJDC (Duschinsky 1953: 454).

Hungary was among the JDC's most extensive postwar programs, with the organization's goal being to establish Jewish relief and cultural institutions that would in-turn facilitate the economic self-sufficiency of Hungary’s nearly 200,000 Jews (American Jewish Committee 1947: 740). Similar to its efforts in other states, in Hungary the AJDC financed and oversaw a variety of organizations: the state-sponsored Jewish umbrella organization, Magyar Izraeliták Országos Irodája (National Office of Hungarian Israelites, or MIOI); MIOI’s welfare arm the Országos Zsidó Segítö Bizottság (National Jewish Relief Committee, or OZsSB); and the Deportáltakat Gondozó Országos Bizottság (National Relief Committee for Deportees, or DEGOB), which worked with the Jewish Agency and the World Jewish Congress to provide food and clothing to arriving deportees. The AJDC also worked closely with the Ministries of Welfare and the Interior (Frojimovics 2005: 280; Zweig 2001, 63). The AJDC's Hungarian program was the most complex, far-reaching and expensive of its European programs, accounting for over a quarter the organization's expenditures in postwar Europe, totaling \$49,585,870 by the program’s formal end in January 1953.

Similar to other European states, substantial portions of this aid entered Hungary in the form of U.S. or other convertible western currencies, although additional aid arrived in the form of commodities, such as coffee, food staples, leather and raw materials. In Hungary, these supplies arrived to the OZsSB via government ministries and the state bank, which transferred the subsidy into Hungarian currency at a pre-arranged rate of exchange. As in other east European states, this flow of goods and stable dollars helped not only Jewish aid organizations, but simultaneously was fundamental in offering some stability to the Hungarian economy more generally. According to Frigyes Görög, AJDC-Hungary director from 1945-1948, the "success" of the 1946 currency reform that sought to counteract postwar hyperinflation, succeeded because of the AJDC's substantial allocation of dollars to Hungary's national accounts. Indeed, as in other east European states, AJDC aid was a substantial, if not the primary source of dollars for the Hungarian treasury, a factor leading then Secretary of the Supreme Economic Council Zoltán Vas to regard it as "the strongest imperialist influence in Hungary," but a necessary one.

Until 1948, the Joint's program assured the daily survival of tens of thousands of Jews through, among other examples, cash and clothing, food in cafeterias and aid parcels, hospitals, and support for orphanages and rest homes. It focused on cultural and communal rehabilitation 
Levine, Zachary Paul. "Concealed in the Open: Recipients of International Clandestine Jewish Aid in Early 1950s Hungary” AHEA: E-journal of the American Hungarian Educators Association, Volume 5 (2012):

http://ahea.net/e-journal/volume-5-2012

with subsidies for Jewish religious, cultural and educational activities across 158 communities, material subsidies and pre-natal programs to new families, job training for thousands of former merchants, and loans and tools to start new cooperatives. Some recipient institutions included Zionist hachsharot and plugot (training camps), which also encouraged members to leave Hungary for Palestine.

Job training was partially a palliative to the broader economic situation and the deteriorating official consumer economy-a result of economic planning favoring heavy industry. As Figure One below illustrates, the effects of the planned economy on real wages was a nearly 20 percent drop in 1950 against an almost 70 percent rise in the cost of living. The 1950-1951 crop failure and increased "requisitioned" exports to the USSR resulted in shortages in industrial products, fuel and food (Duschinsky 1953: 471). Scarce items were available and basic survival was possible through the black market, but at much higher than official prices. People able to maintain work spent up to a quarter of their salaries on basic foods. Prices for sugar and rice were 60-70 percent over official prices, and protein-rich fats and oils were 120 percent over official prices. In 1952, Israel's Chargé d'Affaires Gershon Avner noted that fewer than half of Hungary's then 155,000 Jews (Shapiro 1953: 196) were capable of supporting themselves, even if they had jobs. In February 1953 Shmuel Bentzur, director of Israel's Ministry of Foreign Affairs Eastern Europe Division, reported thousands of pleas from people in need to the Israeli legation for aid, because of the "terrible poverty resulting from high cost of living and diminishing of reserves through selling of private goods."

As Xavier Richet notes in his study of the Hungarian economy, "[t]he combination of low wage levels and expensive durables in limited supply means that a large part of the working population has to resort to second jobs," frequently in a second economy (Richet 1989: 114). The dearth of wages meant that payment for illegally distributed goods and services often arrived in kind with materials "stolen” from workplaces. Legally, such activities were categorized as economic crimes, so that hoarding, black marketeering, and "sabotage” including workplace theft brought sentences of up to a decade in prison (Duschinsky 1953: 453). Yet, regardless of the risks involved, the combination of persistent shortages, and the sudden drop in income for former business and landowners pushed millions of people toward the second economy (Brown 2007: 99-110; Richet 1989: 166, 174). And while authorities prosecuted these activities in some cases, "illegal" economic activities were so prevalent as to be the norm, with authorities tolerating the black market because it constituted a release for pent-up pressure from consumers (Brown 2007: 93). 
Levine, Zachary Paul. "Concealed in the Open: Recipients of International Clandestine Jewish Aid in Early 1950s Hungary” AHEA: E-journal of the American Hungarian Educators Association, Volume 5 (2012):

http://ahea.net/e-journal/volume-5-2012

Figure 1:

Consumer Prices, Nominal Wages, and Real Wages, and Cost of Living in Hungary, 1950-57

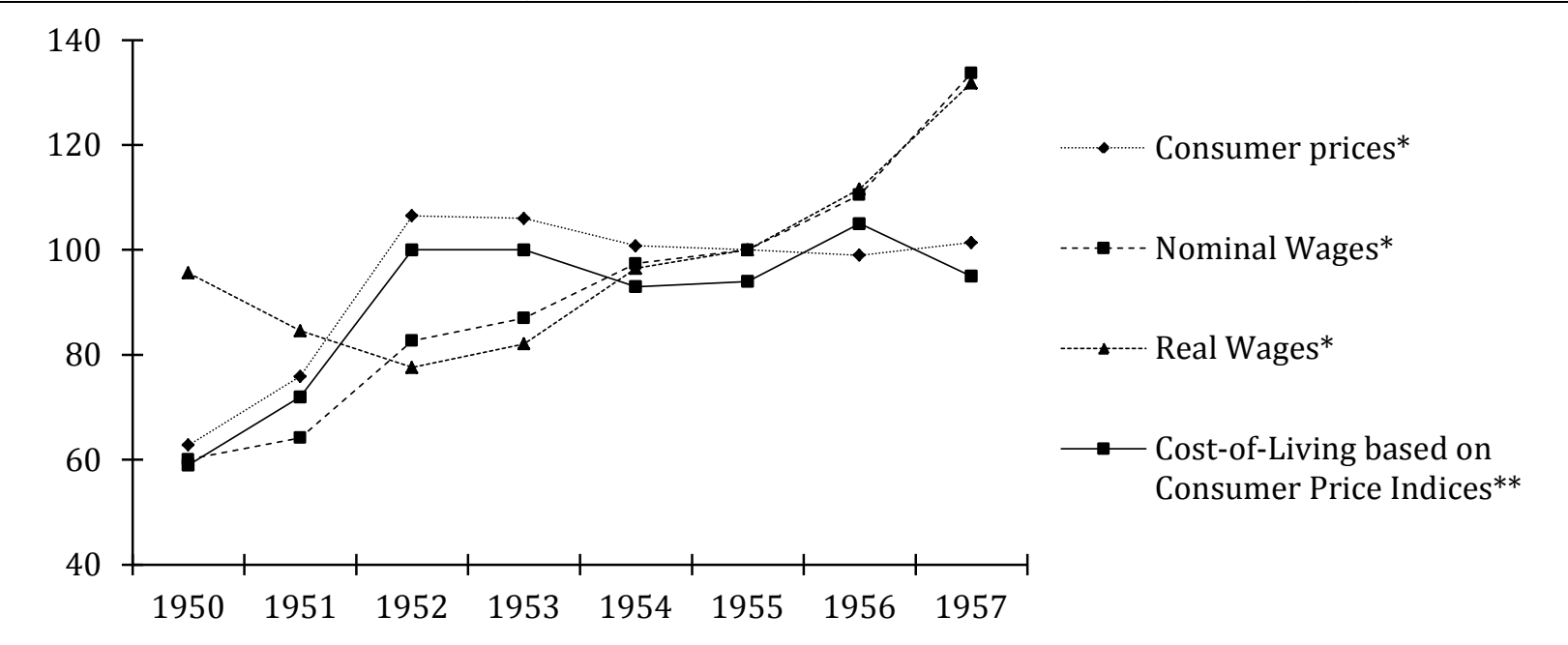

*Basis-point index based on 1955 as the mean (100) for Consumer prices and Wages indices.

**Basis points for Cost of Living are based on 1953 as the mean (100).

Source: Kaser and Radice 1985: 64; Mitchell 1992: 848.

Magdolna Palmai, a Jew in the former Hungarian village of Nagybereg just over the Soviet border (in present-day Ukraine), recalled the close integration of the black market in daily life, and sacrificed sleep for its opportunities for economic gain:

I never had that much flour, lard and sugar than at that time, because one could get everything, but everything was corrupt. The entire system was corrupt. They fixed the norm in the mill and the loss of material during the milling of the wheat, so that the real loss was much less. This way they stole bags full of flour for those who were close to the fire, sold it to the acquaintances or shopkeepers, and we also got it this way from the black market.

There was a joke at that time, which goes like this: they ask Hruscsov [Hungarian spelling for Khrushchev] what he lived off, because one could not live off his salary. He said, 'work during the day and don't sleep during the night' (centropa.org).

Victims of economic nationalization supplemented their diminished incomes through the "illegal" sale of goods and labor (Brown 2007: 67-69). Some former business owners, including the many Jewish merchants retained employment within their previous businesses, though with substantially reduced earnings, and survived by drawing on old connections to supplement this decrease. For example, Miklós Patai produced wine and plum brandy through his fruit export business in Gyöngyöspata, until its nationalization in 1949. To compensate for the sudden drop in his family's income, Patai regularly traveled via motorcycle to nearby towns including Eger to sell wine secretly to legal distributors, though he worried about being caught by the Secret Police (Meschel 1997: 129-30). Another entrepreneur who earned most of his living from the black 
Levine, Zachary Paul. "Concealed in the Open: Recipients of International Clandestine Jewish Aid in Early 1950s Hungary” AHEA: E-journal of the American Hungarian Educators Association, Volume 5 (2012):

http://ahea.net/e-journal/volume-5-2012

market was Peter Cukor, a Jew who moved to Budapest following the nationalization of his family's leather business in Szolnok. Cukor recalls:

My father's uncle worked as a necktie maker in New York City and occasionally he would send us out-of-fashion ties and nylon stockings, which I was able to peddle, illegally, in different nightclubs. My uncle Mishi ... worked in a radio factory in Budapest and was responsible for cutting the back panels of radios out of impregnated cardboard. He managed to lay the design out in such a manner that he had wide strips of the material left over. At night I would go to the factory and Mishi would throw the leftover material over the fence. I collected the stuff and tied it into bundles and then delivered it to various shoemakers. These were my father's connections from the days he worked in leather goods. They in turn used it for making insoles. This was a profitable operation, [as] we got the material for free and sold it for a high price, but the risk was also high. If apprehended, the punishment was severe for stealing state property and dealing in black market goods (Cukor 2004: 98-101).

Given Hungary's economic situation, it should be unsurprising that many people-Jews and non-Jews alike-hoped to emigrate. In 1946 MIOI president Lajós Stöekler admitted to the Anglo-American Committee of Inquiry that roughly 77 percent of Hungary's Jews hoped to emigrate, more than half to them Palestine (Kochavi 2001: 194-195). Between 1946 and May 1948, an estimated 30,000 to 33,000 Hungarian Jews left through Bricha (Flight), the Jewish Agency's program that secretly funneled east European Jews to British-Mandate Palestine (Bauer 1970: 295; Bialer 1990: 63). Hungary’s adjacency to Austria and Czechoslovakia made it an important transit area on the route to Displaced Persons camps in Germany and Austria, where Zionist and Jewish Agency activists massed potential immigrants. At the end of the decade, 30,000 Romanian Jews crossed through Hungary with Bricha escaping drought and famine (Bauer 1990: 61, 151-152).

AJDC leaders in Hungary and elsewhere coordinated with the Jewish Agency's Mossad L'Aliya Bet (Aliya Bet Institution), which managed Bricha, to direct the flow of Jewish migrants, share information, and facilitate funding from the U.S. Many of the people involved in emigration and later with clandestine aid had worked on wartime rescue activities, including AJDC-Hungary’s director Frigyes Görög. Working through the OZsSB, Görög and his successors provided housing, food and clothing for Hungarian migrants and negotiated visas and the transfer of property with authorities. Initially Hungarian authorities supported the flow of Jews out of Hungary, which removed a humanitarian burden from the government, and antagonized British interests in Palestine_-a fact that pleased Hungary's allies in the Soviet Union. (Kochavi 2001: 193). But with the establishment of the western-leaning state of Israel, Hungarian authorities' support waned. Although legal emigration from Eastern Europe generally was still possible in theory, authorities there increasingly restricted the categories of people permitted to leave, slowed and eventually stopped processing exit visas, effectively ending emigration to Israel in 1952.

After 1948, the AJDC became a locus of growing Cold-War animosities. Unease among Hungarian authorities over the organization's considerable economic role there, suspicion that its American staff and their Israeli partners supplied industrial and military intelligence to U.S. 
Levine, Zachary Paul. "Concealed in the Open: Recipients of International Clandestine Jewish Aid in Early 1950s Hungary” AHEA: E-journal of the American Hungarian Educators Association, Volume 5 (2012):

http://ahea.net/e-journal/volume-5-2012

officials, and claims that the AJDC supported black market trade and unsanctioned Jewish emigration, resulted in increasing government intervention in the Joint's administration, and, in December 1949, resulted in the arrest and torture of some AJDC-Hungary staff, including its American director Israel Jacobson. In April 1950, under State Department advice, the AJDC's American workers left Hungary. The organization continued to subsidize Jewish social services through MIOI, and the Központi Szociális Bizottság (Central Social [Service] Committee, or KSzB), the OZsSB's successor. From 1950-1953, AJDC staff traveled to Hungary to inspect the KSzB's program. Yet, they distrusted the government-run MIOI and KSzB, and were skeptical of any MIOI or KSzB statistics on aid distribution, and reports on the condition of the Jewish population and institutions, let alone anecdotes on the effect of this subsidy. Consequently, AJDC administrators came to rely instead on reports from Mossad L'Aliya agents, HungarianJewish expatriate organizations, and American diplomats.

In an effort to press Hungarian authorities either to care for their own Jewish citizens or let their organization continue without hindrance, AJDC leaders curtailed their monthly allocations to MIOI from several hundred thousand dollars in 1949 , to about $\$ 25,000$ by mid1952. This reduction strangled Jewish social welfare programs, and further antagonized communist authorities that felt AJDC leaders had unduly reduced the subsidy in response to emigration restrictions to Israel, which was partially true. Finally, in January 1953, under pressure from government authorities, MIOI returned that month's check from AJDC, affecting the program's cessation. The closure of the World Jewish Congress' Budapest office two months later signaled the closure of official routes for aid to Hungarian Jews from the U.S. On the eve of the AJDC's program closure, Israeli Chargé d'Affaires in Hungary Gershon Avner reported, "the greatest fear for tens of thousands of people is for their next piece of bread, who received help from the Joint in one way or another" [sic]. They were "Mostly old people and orthodox whose only and last source of income it was." Avner continued that he knew for certain of at least one case of suicide of a Jew unable to support himself.

MIOI and KSzB leaders attempted to maintain Jewish medical and feeding facilities by selling off communal property to their state-run counterparts, but at the expense of standards for care. Government authorities enfolded Jewish hospitals, old age homes, orphanages, cashdistribution programs, and other relief that ran out of resources, into state institutions. State-run facilities maintained substantially lower feeding and shelter standards, and offered little if any framework for Jewish cultural and religious needs, including kosher food. These reductions especially imperiled Jewish forced-labor and concentration camp survivors unable to support themselves, Jewish victims of nationalization still unable to find adequate employment, and roughly 10,000 religiously observant Jews whose refusal to work on the Sabbath made them ineligible for employment or state welfare.

Individuals and households heretofore reliant on Jewish communal institutions found themselves with few options for assistance. Most welfare in Hungary arrived almost exclusively to workers in government enterprises, the highest proportion to heavy industry. This aid came as "benefits-in-kind such as socialized healthcare, housing, childcare, eating facilities, as well as benefits-in-cash such as family and marital allowances," and vouchers for purchases at stateowned stores (Duschinsky 1953: 453; Haney 2002: 25-6). Access to these benefits was nearly impossible for the hundreds of thousands of people ejected from or on the margins of the state workforce, including thousands of unemployed and underemployed Jews, who were simply not entitled, especially if they had been stigmatized by the state as "non-productive." 
Levine, Zachary Paul. "Concealed in the Open: Recipients of International Clandestine Jewish Aid in Early 1950s Hungary” AHEA: E-journal of the American Hungarian Educators Association, Volume 5 (2012):

http://ahea.net/e-journal/volume-5-2012

The collapse of the AJDC's program by no means meant the collapse of Jewish aid from abroad. The JDC-Israeli collaboration that formed around clandestine emigration to Israel and welfare to migrants filled the vacuum with the creation of two institutions. The first was created in 1952 by the Israeli government's Liaison Bureau of the Israel Ministry of Foreign Affairs, or Lishka by its Hebrew acronym, which collected information and administered individual aid. The second was created in Switzerland in 1953. Known as the Society for Mutual Aid (SSE by its French acronym), this organization directed AJDC funds to the Lishka and represented Jewish aid providers' interests to communist governments. At the same time, the collapse of any possibilities for large-scale legal or clandestine Jewish emigration from Hungary led the Israeli government to close the Mossad L'Aliya in 1952, and establish the Lishka in its place. This new organization adapted the Mossad's connections with East European Jews and communist governments to expand aid to Jews across Eastern Europe (Beizer 2009: 115-117). With offices in Israel, Paris, Geneva and Vienna, Lishka agents worked with and out of the Israel legations and embassies. These agents maintained contact with Jewish populations at religious services, where they exchanged messages and information, which they shared with AJDC officers in the West. Lishka's top agent in Hungary was Israel's Chargé d’Affaires Gershon Avner, who travelled throughout Hungary to inspect the size, composition, and economic condition of Jewish communities, and met with Jewish religious leaders, communal officials in the orthodox and Neolog camps, members of Agudat Israel, and Jewish youth including athletes in the Macabbi sports club, among others.

AJDC leaders hoped to send aid into Hungary in the hands of Lishka agents traveling around the country. However, as an American organization at the height of the McCarthy "Red Scare,” AJDC administrators could hardly justify the appearance of sending cash or material into a state with which the U.S. was technically engaged in "economic warfare." In March 1953, the AJDC and Lishka together established the SSE, a "paper organization" that "covered” the AJDCIsraeli partnership, and provided a means for regularized AJDC funding for Lishka from the Joint's Relief-in-Transit budget that funded activities that might have contravened U.S. law (Beizer 2009: 117). The SSE’s Swiss chairman, Erwin Haymann, had years of experience channeling money from the U.S. for Bricha and other clandestine activities. Funds traveled through the SSE and on to Lishka agents who received U.S. dollars or another western currency and exchanged them into Hungarian forints on the black market in Vienna. Subsequently, these forints traveled via diplomatic pouch or in the suitcase of an apparent traveler to the legation in Budapest, whose staff distributed the cash around the country.

\section{Clandestine Cash: 1950-1953}

As early as 1950 the AJDC provided cash that Mossad L'Alya agents distributed directly to people ineligible for state and MIOI/KSzB aid, among them Zionists branded as political enemies, and orthodox Jews who refused to work on the Sabbath. These efforts expanded in May-July 1951 when Mátyás Rákosi’s regime “cleansed” Budapest and other cities of their “class enemies.” This program of kényszerlakhely (compulsory residence) meant the expropriation of properties from tens of thousands of merchants, professionals, and other “economic enemies," who were exiled to remote areas in the provinces. Of the roughly 14,000 former aristocrats, army officers, business owners and so-called “class-enemies" evicted from their homes, Jews comprised 14-22 percent, whereas they constituted 1-2 percent of the general population (Kovács 2003: 138). Like thousands of other Hungarians, following the dreaded 
Levine, Zachary Paul. "Concealed in the Open: Recipients of International Clandestine Jewish Aid in Early 1950s Hungary” AHEA: E-journal of the American Hungarian Educators Association, Volume 5 (2012):

http://ahea.net/e-journal/volume-5-2012

csengőfrász (doorbell terror), Paul Hollander, a Jew from Budapest, had 24 hours notice to prepare for the move. To Hollander, this "felt more like deportation since we were not allowed to go there on our own but were picked up during the night by a truck (which already had on it another family and their belongings)” (Hollander 1997: 106-107).

For many Jews who had suffered under fascism, a new round of state-orchestrated deportations, and the unspoken but nonetheless very real threat of being murdered, were too much. Similar to the general population in Hungary, news of these expulsions spread panic across the Jewish population and among Jewish organizations abroad. At least 42,000 Jews sought help from the Israeli legation in July 1951, and legation staff expected that up to 100,000, or 80 percent, of Hungary's Jews would apply to immigrate to Israel. According to an Agudas Israel representative in August, "Tens of thousands from all classes, including a very high proportion of Jews, had already been deported... Many were committing suicide because they were convinced that deportation to concentration camps was ultimately followed by extermination.” Péter A. Csángó described how deportation affected his aunt:

Several of my relatives were victims of the forced evacuation. Of these I would like to mention my aunt, the chemical engineer Dr. E.L., who returned from Mauthausen concentration camp. A few years later she was deported to the countryside with her husband and small daughter. ... Their apartment in Budapest was given to another family and they had to live in a village in very primitive circumstances for several years. My aunt later emigrated to the United States, but the hardships were too much for her and she ended her life in 1965 (Csángó 1997: 200).

Resettlement victims traveled under police guard to remote villages in eastern and eastcentral Hungary. Many deportees_-Jewish and non-Jewish_came from well-to-do families, and, as Jewish deportees who later escaped to Israel reported, most had "never been accustomed to manual labour and were incapable of looking after themselves and taking care of their own daily needs.” Hollander's distinction between his old and new homes was emblematic of this situation:

At that time in Hungary the gulf between city and countryside was profound; there was only one real city: Budapest. Small towns or cities ... were not city-like and not considered desirable places of residence by the more educated or better-off segments of the population. Villages were regarded, with good reason, as backward, uncivilized places, lacking basic amenities and services such as running water, paved roads, telephones, decent shops, libraries, movie theatres and other places of entertainment (Hollander 1997: 107-08).

Deportees arrived to their new "homes" with few personal possessions, and found little food, shelter and clothing, and few if any legal employment opportunities. "We were assigned to a small house (all of us in one room)," writes Hollander, "thus imposed on a peasant family also regarded with disfavor by the authorities. They were classified as 'kulaks'... I lived in the village for two years under police supervision. We were, for the most part, not obliged to work, because not much work was available...” (Hollander 1997: 107-08). As "unproductive elements,” all deportees had little if any rights to state assistance. Accordingly, Jewish deportees 
Levine, Zachary Paul. "Concealed in the Open: Recipients of International Clandestine Jewish Aid in Early 1950s Hungary” AHEA: E-journal of the American Hungarian Educators Association, Volume 5 (2012):

http://ahea.net/e-journal/volume-5-2012

had no rights to Jewish welfare programs from the KSzB (a growing collection of memoirs and data on the deportees has become available in recent years. See, for example, Fenyves 2011).

With the AJDC reduction of its allocations after mid-1951, KSzB administrators focused their dwindling resources on Budapest where the vast majority of Jewish aid institutions were concentrated, which meant a cut in most of the KSzB's services to the roughly 20,000 Jews scattered in smaller towns villages. In contrast to the few thousand Jewish "enemies of the people," so-called “elements hostile to the government” who were already ineligible for KSzB assistance, according to AJDC Assistant Director General for European Affairs Charles Jordan, the countryside held "another much larger group of 'undesirables'; i.e., people too old or too sick belonging to the former bourgeoisie” or too religiously observant to find employment.

Rural areas contained about 10,000 orthodox Jews, many of whom were unwilling to work on Saturdays, a requirement for employment in many state enterprises (Duschinsky 1953: 455). Government employment regulations made no allowance for religious observance, and welfare laws precluded any welfare, including from the KSzB, from going to individuals deemed capable of working who refused to do so. Consequently, many provincial orthodox communities, such as the 50-family mostly orthodox community in the southern village Bonyhád, had virtually no economic stability. In his report on that community, Israeli Chargé d'Affaires Gershon Avners added that the children were in a similar position as their parents because mandatory school attendance on Saturdays precluded Sabbath observance.

AJDC administrators, Israeli legation workers, and American diplomats agreed that under these circumstances, this community and the dozens of other provincial Jewish communities had few chances for survival. In response, AJDC leaders and their Israeli partners developed their own routes to send cash to these people in the Hungarian provinces, either until conditions improved, or until Israel could broker an emigration agreement. Giving cash directly to the needy had been a central form of AJDC relief since the organization's inception, and constituted a component of OZsSB/KSzB relief until mid-1953. Currency was easy for aid providers to distribute, and with cash recipients could purchase whatever they needed to survive. Charles Jordan explained the necessity for these efforts to U.S. officials in Budapest:

[W]e are sending some money into Hungary for the relief of aged, unemployable persons, former middle class people who are ineligible for assistance by the Hungarian Government as a consequence of the class struggle. We feel strongly about these people who have been stripped of all their possessions as a result of nationalization measures and who would probably die from starvation if it were not for our help.

This AJDC-Israeli cash-aid program was relatively small at its inception at roughly Ft150,000 $(\$ 12,776)$ in early 1951. It focused on the orthodox Jews in the provinces, a few hundred Zionist activists, and individuals with connections to major donors to Jewish philanthropies. KSzB aid was available to most Jews throughout Hungary until mid-1951 with the expulsions from the cities and the subsequent contraction of the KSzB's budget over the next two years. These factors and the collapse of the AJDC's subsidy to the KSzB in early 1953 fueled the rapid expansion of the AJDC-Israeli program in the provinces and eventually into Budapest. In January 1953 the program’s monthly budget was Ft50,000 (\$4,259), growing to nearly Ft300,000 $(\$ 25,554)$ the following May. These funds were intended to provide for their 
Levine, Zachary Paul. "Concealed in the Open: Recipients of International Clandestine Jewish Aid in Early 1950s Hungary” AHEA: E-journal of the American Hungarian Educators Association, Volume 5 (2012):

http://ahea.net/e-journal/volume-5-2012

recipients' only survival and were far below the wages in state-enterprises, but higher than KSzB aid. Figure 2 compares these sums from mid-1953, just before the KSzB ended its cash-aid program. AJDC-Israeli aid was lower in Budapest because of the concentration of KSzB and other welfare institutions in that city.

Figure 2: Monthly AJDC-Israeli and KSzB Cash Aid, and Industrial Workers’ Wages, Mid1953 (Forints)

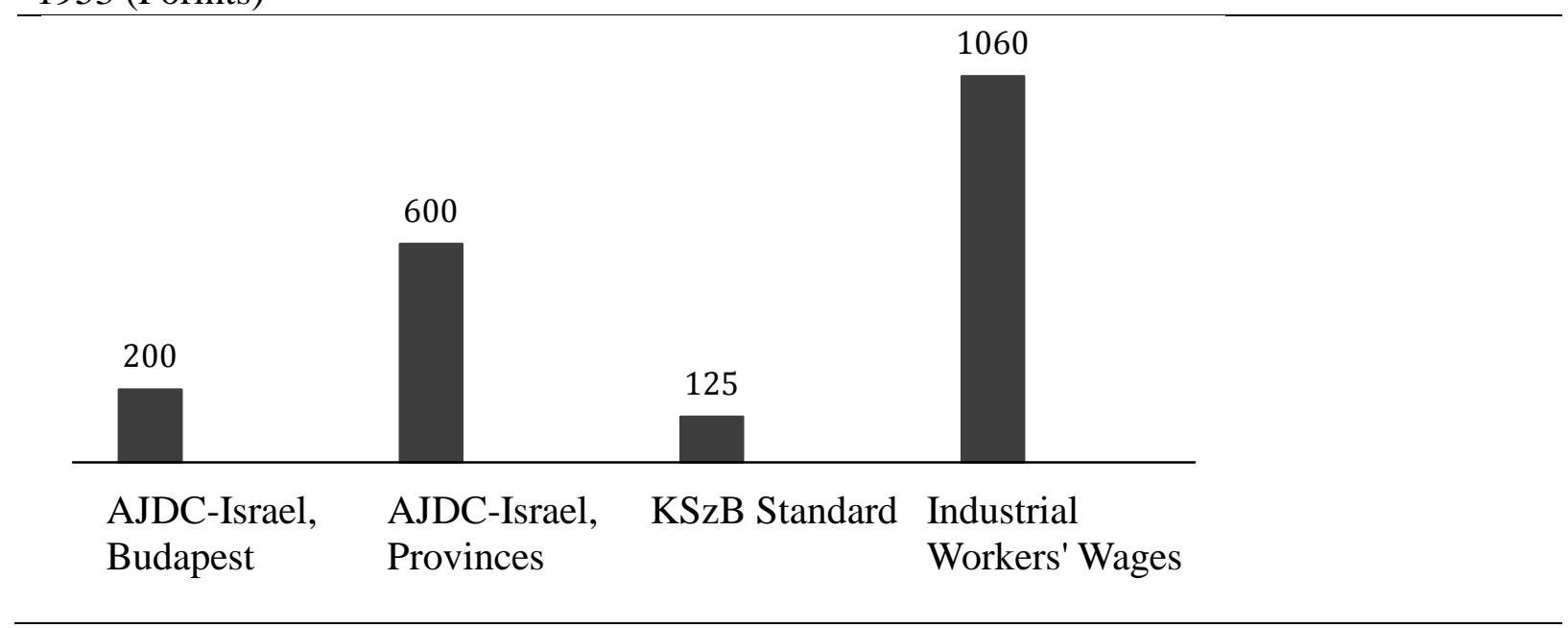

Getting cash into recipients’ hands started in the offices of the Israeli legation. From there, agents traveled around Hungary, each with thousands of dollars to hand out to needy individuals. They correctly assumed that they were under continual police surveillance, and agonized over the risks of being caught, in part as the result of rumors of these activities among Hungarian Jews. Gershon Avner was uncertain about the wisdom of this brazen experiment. In March 1953 he wrote to Charles Jordan:

Our own action is going on under increased difficulties... Those who take from us larger amounts for further distribution are frightened to move about with receipts or even lists of names in their pockets... And of course people here talk, talk, talk, and it's quite dangerous to enlarge the orbit.

The combination of rumors and perceived threats from government authorities, coupled with the need to aid an increasing number of recipients, led Legation staff to turn toward HungarianJewish intermediaries. These individuals typically included Rabbis, doctors and KSzB employees who maintained a wide range of contacts across Hungary's Jewish population who had cause to travel regularly between Budapest and the rest of the country. The main criterion for an intermediary was his or her trustworthiness to hand out on average Ft1,000 - 10,000 (\$85\$852) with every “outing.” Confirmation that these funds reached their intended destinations was nearly impossible since most recipients were apprehensive, if not terrified, to acknowledge receiving help from non-state institutions and would not sign a receipt. 
Levine, Zachary Paul. "Concealed in the Open: Recipients of International Clandestine Jewish Aid in Early 1950s Hungary” AHEA: E-journal of the American Hungarian Educators Association, Volume 5 (2012):

http://ahea.net/e-journal/volume-5-2012

In spite - or perhaps because — of the overwhelming need across the Jewish population, determining the few recipients was, as Charles Jordan described, "by rule of thumb." This decision-making process was made all the more problematic by a dearth of data on the locations and statuses of the neediest people. The AJDC and their Israeli counterparts received some information from family and a network of Hungarian-Jewish expatriate organizations headed by former leaders from Hungary's Jewish community. Some of these recipients were people living and working in Jewish welfare institutions, and current and former MIOI, KSzB and AJDC employees. Funds went to yeshivot, homes for the elderly and synagogues outside of Budapest, and subsidized meals in soup kitchens. Still, substantial numbers of needy Jews lacked connections with other Jews and institutions. Responsibility for keeping track of this group was taken on by the intermediaries and Israeli agents who continued traveling throughout Hungary to make contact with these individuals. The program operated in at least 33 cities, towns and villages by mid-1953.

Yet, 1953 brought an unexpected pause in the vary challenges that sparked the creation of the Lishka and SSE, starting with Stalin's death in March, followed by signs of political, social and economic reforms across the region. In June, U.S. Economic Consul in Budapest Seymour Finger described a relaxation to "pre-Jewish-doctor days," and noted that authorities no longer regarded the AJDC as an agent of Western imperialism. The release of some prisoners and deportees over the course of 1953, suggested, as an Israeli legation communiqué noted, that "[t]he atmosphere of persecution disappeared almost completely." MIOI and the KSzB, and their parent government agency, the State Church Council, had new leadership actively discussing resuming Jewish aid from abroad. The KSzB's new Chairman, Miklós Vida, maintained regular contact with the SSE though Lishka. These developments alongside the desperate state of Hungary's economy after five years of communist rule, suggested to AJDC and Israeli aid providers that they might be able to expand if not formalize their clandestine efforts with the cooperation of Hungarian government authorities.

\section{Clandestine Parcel Aid: 1951-1955}

After the summer of 1953, AJDC-Lishka leaders redirected much of their aid efforts from cash distribution toward gift parcels that recipients could sell or barter, which AJDC-Lishka purchased through Hungary's state-run consumer products and food import/export monopoly Iroda Külföldi Kereskedelmi Akció (Office of Foreign Commercial Action, or IKKA). The carrot for authorities presiding over Hungary's wrecked economy would be the promise of western currencies passing into state enterprises, affecting the "importation" of scarce goods into the consumer economy through the black market. Indeed, many households, Jewish and non-Jewish alike, essentially lived off of IKKA parcels sent, or paid for, by family or expatriate organizations abroad.

Similar to other import/export schemes across the communist world, IKKA charged exorbitant prices to send money and send gifts to people in Hungary. IKKA was a vehicle through which communist authorities acquired foreign capital for the government and scarce goods for the consumer economy. Because parcel recipients could use what they received for their own "side" enterprises, Hungarians had at least some access to a variety of goods including foodstuffs such as coffee, tea, flour, meat and cheese, as well as clothing, accessories (such as Swiss watches), shoes, cigarettes, and finished goods such as sewing machines and bicycles. In 1951, roughly one-third of all IKKA packages in Hungary went to deportees who sold or 
Levine, Zachary Paul. "Concealed in the Open: Recipients of International Clandestine Jewish Aid in Early 1950s Hungary” AHEA: E-journal of the American Hungarian Educators Association, Volume 5 (2012):

http://ahea.net/e-journal/volume-5-2012

bartered parcel contents. Their potential impact was impressive. According to one IKKA broker, sales of parcel contents fetched up to 400 percent of their initial price, which recipients usually used for food staples such as flour and sugar. A \$12 parcel garnered up to Ft570, 2-4 times KSzB's monthly cash relief.

The origins of clandestine parcel-aid to Hungarian Jews began alongside cashdistribution with the deportations in 1951. The sale of parcel contents constituted recipients' primary income. Paul Hollander noted that, after deportation, his family's "livelihood was largely provided by relatives living abroad in Mexico and England who sent us packages, mostly secondhand clothing my mother was able to sell or exchange for food" (Hollander 1997: 107108). Between 1951-1953, the AJDC leaders in Paris entered into a series of ad hoc agreements with expatriate organizations to finance the distribution of parcels from the International Red Cross (IRC) or from IKKA. Yet working through other organizations to obscure the AJDC's role brought administrative costs that detracted from aid. Gradually the Joint took over for these organizations, which continued to raise money and provide information on potential recipients.

Like the cash distribution scheme, the parcel program was far from smooth at its outset. Recipients' leeriness over accepting parcels from an unknown sender or non-IKKA (IRC or other) parcels combined with scarce information on potential recipients meant that as late as September 1953, the AJDC only had addresses for 2,565 families in a Jewish population where and estimated nearly 70,000 people were in need of assistance. Charles Jordan recognized that each package needed to "have a sender who would be acceptable to the Hungarian authorities and from whom to receive packages would not embarrass the individuals in Hungary and other countries." Indeed, he wrote, "the Hungarian Gvt. [sic] will allow only food to be sent which is purchased in Hungary and for which they receive the dollars," that is through IKKA.

In June 1953, with permission from Hungary’s authorities, Miklós Vida, and MIOI’s new president Lajós Hevesz, requested the establishment of permanent cultural contacts with the Mosaika Församlingen (Jewish Federation) in Stockholm, the Chief Rabbi of Antwerp, and in September with the SSE in Switzerland. The response from the SSE arrived as an inquiry if MIOI's welfare programs might benefit from outside help. Vida and Hevesz approached János Horváth, the head of the State Church Council, and suggested that MIOI provide lists of relief candidates to the SSE, which would in turn purchases IKKA parcels for those recipients. Hungarian authorities were interested but suspicious of these organizations' motives. Over the next four months they negotiated with the SSE for a way for the AJDC to finance and, with the Lishka, administer aid parcels for Jews across Hungary.

A major break in these negotiations came that September with the visit to Hungary of a Swiss Jewish businesswoman, Mrs. Lajós Buchwald - a former Hungarian and activist in wartime Zionist rescue efforts-who ran an import business with IKKA's parent agency Monimpex. Buchwald approached Monimpex about a contract for monthly parcel distribution paid by the SSE. A few weeks later, Buchwald, came to an agreement with representatives from Hungary's State Bank, the Church Office and IKKA for the distribution of 200 packages monthly to benefit 400 families, or 1,000 people located mostly outside of Budapest, and 500 parcels monthly for soup kitchens providing one meal per day to 2,500 "poorest of the poor." Of crucial importance for the Hungarian authorities in this arrangement was that these activities attract no publicity.

The program grew quickly. By March 1954, program administrators had compiled a roster of 14-15,000 applicants, and had funds for 34,000 parcels annually. Two years later, the 
Levine, Zachary Paul. "Concealed in the Open: Recipients of International Clandestine Jewish Aid in Early 1950s Hungary” AHEA: E-journal of the American Hungarian Educators Association, Volume 5 (2012):

http://ahea.net/e-journal/volume-5-2012

SSE spread 42,000 parcels across 24,000 Jewish households, with most households receiving one or two parcels in 1956. A June 1955 review found that recipients usually had no idea if they had received one of the “Joint” parcels, as Charles Jordan described in 1955:

Thousands of packages arrive in Hungary all the time, sent from Switzerland. Most of the people have been nominated without their actual knowledge. The story therefore goes around that some mysterious philanthropist - probably the Joint - has in some miraculous way gotten ahold of these names and sends them a package occasionally without any prompting. Then you get the case of a person in Hungary who requests a relative or friend to secure a parcel for him. That person in the U.S. goes to the, let's say, [United Hungarian Jews of America] and that organization tells him they will arrange for a parcel to be sent. Then this person in the U.S. writes to the person in Hungary and tells him that. But the person in Hungary never receives a parcel which is identified as coming from the [Union of Hungarian Jews in American]. Even though he receives parcels from some unknown source in Switzerland he does not associate the two because so many other people who never knowingly put their names on the list have a parcel of that kind.

In the slowly improving economic climate of the New Course Reforms, these parcels were supposed to augment household incomes, in contrast to the early parcel program when parcels were the soul income for some deported families. Rather, parcel contents helped recipients to escape the realities of early-communist Hungary. For example, a Jewish high school teacher from Budapest and Székesfehérvár who left Hungary during the 1956 uprising, noted, "During my study time my mother sent me through several years to the tourist hospice at Dobogókő for 2 or 3 weeks recreation ... The money came by selling things we got in parcels from America.” The parcels typically contained used clothing, and arrived with sufficient regularity that he rarely needed to purchase clothing aside from socks and underwear. However, as parcel aid grew, so did the visibility of its recipients. Charles Jordan worried, "the queuing up of people in front of IKKA offices to receive their parcels creates some unhappy feelings among the non-Jewish population.” In spite of the program's successes in a relatively short period of time, it seemed that its administrators needed to consider ways to distribute aid less conspicuously, including "spread[ing] the sending of parcels more thinly, or find a way of getting money to the people instead.”

Local Jewish leaders were by no means unanimous in supporting this scheme, and some Hungarian Jewish leaders perceived this form of outside aid as a threat to the few Jewish local aid programs that had not yet collapsed. Writing in June 1954, Lajós Lévy, a doctor in the KSzB, worried that aid flowing through a third party would merely serve as a pretext for future persecution at the hands of Hungary's communist leadership:

I must say that it would be a great and even dangerous mistake to believe that such extensive activities, talked about by hundreds of people, could be held secret before the authorities. Any individual action must necessarily be unjust and will give rise to suspicion. 
Levine, Zachary Paul. "Concealed in the Open: Recipients of International Clandestine Jewish Aid in Early 1950s Hungary” AHEA: E-journal of the American Hungarian Educators Association, Volume 5 (2012):

http://ahea.net/e-journal/volume-5-2012

Neither MIOI nor KSzB can or should take note of these 'underground' activities because should the authorities stop tolerating them for political or other reasons, the administration of MIOI and KSzB would be drawn into any investigation.

Lévy suggested the JDC work through the International Red Cross as an intermediary with authorities. Yet, at the same time, government authorities' willingness to invite parcel-based aid, and even welcome its expansion, was rooted in Hungary's economic context of constant shortages, a flourishing black market, and the state's chronic lack of liquid capital for foreign trade. A year after the first agreement between Buchwald and MIOI, AJDC's annual budget for parcels to Hungary had grown to $\$ 700,000$, equaling 5.48-8.29 percent of Hungary’s national accounts totals for 1954 (Kaser and Radice 1985: 45; Mitchell 1992: 901), at a time of sluggish economic growth, diminished employment and industrial output, and a drastic fall in income and investment (World Economic Report 1955: 19-50).

By mid-1954, the SSE began receiving millions of dollars annually through the AJDC indirectly from the Conference on Jewish Material Claims against Germany. The SSE's budget for Hungary grew dramatically, and was certainly crucial in March 1955 when SSE chairman Erwin Heymann traveled to Budapest to negotiate for a further expansion of the parcel program, and for direct subsidies from the SSE to the Hungarian Jewish community. The result was an agreement for improved parcel pricing and monthly subsidies of \$25,000 to Jewish welfare programs (the same amount at the end of the AJDC's program in 1953), in the form of medicines and Chevrolet Bel Airs, which government authorities "transferred" into forints for MIOI. After 1956, the parcel and direct funding negotiations were the basis for the expansion of Jewish relief and cultural assistance throughout Eastern Europe. These included resumption of emigration agreements between Israel, Hungary, Romania, Poland and Yugoslavia, Nachum Goldmann's unofficial meetings with east European Jewish and government representatives in Paris in October 1956, Hungary's re-affiliation with the World Jewish Congress a year later, the reestablishment of the AJDC's program in Poland in 1957, and later establishment of clandestine aid programs in Czechoslovakia and the Soviet Union.

The wide-reaching consequences of this program, especially on the Hungarian street, raise a question of how these activities could remain a secret. Knowledge that aid was arriving to Hungarian Jews from abroad in some organized regimen was of course widespread among aid funders, providers, recipients, and government authorities. Government authorities on both sides of the "Iron Curtain" knew about, approved, and, negotiated these programs. Jewish leaders, and many of their organizations' donors, including German government representatives negotiating with the Claims Conference, approved the uses of these funds. The absence of much - if anypublicity over these activities, and the circumvention of financial, trade, and public-relations obstacles, created the illusion of the AJDC's noninvolvement, and satisfied stakeholders. In a sense, the AJDC-Israeli SSE occupied a position between east and west, through ongoing conversation and cooperation between Jewish relief workers and government representatives on both sides. Though the simultaneous growth of east-west hostilities was a prelude to the end of AJDC's assistance, the Cold War context subsequently set the terms of how aid could be distributed - through third parties and in the form of scarce consumer and other items. So long as no money or material appeared to move directly between the AJDC in the U.S. and Eastern Europe, help could reach the needy. 


\author{
Archival Sources \\ American Jewish Joint Distribution Committee Archives, New York, NY \\ American Jewish Joint Distribution Committee Archives, Jerusalem \\ American Jewish Archive, Cincinnati, $\mathrm{OH}$ \\ American Jewish Historical Society, NY \\ Central Archives for the History of the Jewish People, Jerusalem \\ Central Zionist Archive, Jerusalem \\ Harman Institute Archives, Hebrew University Jerusalem \\ Hebrew Immigrant Aid Society Home Archives, New York, NY \\ Israel State Archives, Jerusalem \\ United State National Archives and Records Administration, College Park, MD \\ YIVO Institute for Jewish Research, New York, NY
}

\title{
Works Cited
}

American Jewish Committee. 1947. American Jewish Year Book, 1947-1948. Vol. 49. Ed.

Morris Fine Harry Schneiuderman. Philadelphia: Jewish Pulblication Society of America.

Bauer, Yehuda. 1970. Flight and Rescue: Brichah. New York: Random House.

---. 1994. Jews for Sale?: Nazi-Jewish Negotiations, 1933-1945. New Haven: Yale University Press.

---. 1989. Out of the Ashes: The Impact of American Jews on Post-Holocaust European Jewry. 1st ed. Oxford; New York: Pergamon Press.

Beizer, Michael. 2009. "'I Don't Know Whom to Thank": The American Jewish Joint Distribution Committee's Secret Aid to Soviet Jewry." Jewish Social Studies: History, Culture, Society 15.2. 111-136.

Bialer, Uri. 1990. Between East and West: Israel's Foreign Policy Orientation, 1948-1956. Lse Monographs in International Studies. Cambridge; New York: Cambridge University Press.

Borhi, László. 2004. Hungary in the Cold War, 1945-1956: Between the United States and the Soviet Union. Budapest; New York: Central European University Press.

Brown, Karl. 2007. Regulating Bodies: Everyday Crime and Popular Resistance in Communist Hungary, 1948-1956. Dissertation. University of Texas.

Csángó, Péter A. 1997. "A Split World." Red Star, Blue Star: The Lives and Times of Jewish Students in Communist Hungary, 1948-1956. Eds. Andrew Handler and Susan V. Meschel. Boulder, New York: East European Monographs; Distributed by Columbia University Press. 197-202.

Cukor, Peter. 2004. Before the Silver Chord Is Snapped: Looking Back on My Journey. Xlibris Corporation.

Duschinsky, Eugene. 1953. "Hungary: Under the Communist Heel." The Jews in the Soviet Satellites. Ed. American Jewish Committee. Syracuse: Syracuse University Press. 373489.

Ettinger, Amos. 1992. Blind Jump: The Story of Shaike Dan. New York: Cornwall Books. Fenyves, Katalin. 2011. Review of 
Levine, Zachary Paul. "Concealed in the Open: Recipients of International Clandestine Jewish Aid in Early 1950s Hungary” AHEA: E-journal of the American Hungarian Educators Association, Volume 5 (2012): http://ahea.net/e-journal/volume-5-2012

\section{Families}


Levine, Zachary Paul. "Concealed in the Open: Recipients of International Clandestine Jewish Aid in Early 1950s Hungary” AHEA: E-journal of the American Hungarian Educators Association, Volume 5 (2012):

http://ahea.net/e-journal/volume-5-2012

World Economic Report 1953-1954. 1955. New York: United Nations.

Zweig, Ronald W. 2001. German Reparations and the Jewish World: A History of the Claims Conference. 2nd ed. London; Portland: Frank Cass. 